\title{
Immobilized Triazine-Type Dehydrocondensing Reagents for Carboxamide Formation: ROMP-Trz-Cl and ROMP(OH)-Trz-Cl
}

\author{
Kazuhito Hioki, ${ }^{a, b}$ Satomi Kameyama, ${ }^{a}$ Shohei Tani, ${ }^{a}$ and Munetaka Kunishima ${ }^{*, a, b}$ \\ ${ }^{a}$ Faculty of Pharmaceutical Sciences, Kobe Gakuin University; ${ }^{b}$ Life Science Center, Kobe Gakuin University; Chuo-ku, \\ Kobe 650-8586, Japan. Received December 28, 2006; accepted February 8, 2007; published online February 9, 2007
}

New triazine-type dehydrocondensing reagents, such as ROMP-Trz-Cl and ROMP(OH)-Trz-Cl, were synthesized by a ring opening metathesis polymerization (ROMP) method, and these showed higher loading than conventional polymer-supported condensing reagents. These polymers effect the formation of amides in good yields by addition of a mixture of carboxylic acid, amine and NMM. ROMP(OH)-Trz-Cl, which contains hydroxyl groups in the polymer chain, gave amides in good yields even in $\mathrm{MeOH}$.

Key words triazine; immobilized reagent; dehydrocondensation; ring opening metathesis polymerization (ROMP); amide

The advance in combinatorial chemistry has resulted in the development of solid-supported reagents that can be applied to automated synthesis of a target molecule. As a result, many useful reagents that are well established in the field of solution-phase chemistry have been applied to immobilized reagents. ${ }^{1-9)}$

There have been some recent reports on the preparation of immobilized reagents for dehydrocondensation. ${ }^{10-18)}$ However, since most of these reagents are immobilized by connecting dehydrocondensing reagents to insoluble carriers such as polystyrene and silica gel, they would be prepared by inefficient chemical transformation on the insoluble carrier under heterogeneous conditions. In addition, the weight proportion of the solid carrier relative to the amount of solidsupported reagent is generally high, which inevitably results in the generation of large amounts of waste; this is a serious problem common to solid-supported reagents. To resolve this issue, we developed a new immobilized triazine-type dehydrocondensing reagent by polymerizing the dehydrocondensing reagent itself. ${ }^{19)}$ This polymer reagent is based on the condensing agent, 4,6-dimethoxy-1,3,5-triazinyl-2-methylmorpholinium chloride (DMT-MM) $)^{20-26)}$ and is a crosslinked polymer prepared by co-polymerizing tetra(ethylene glycol) bis(4-chloro-6-methoxy-1,3,5-triazin-2-yl) ether and tris(2-aminoethyl)amine, which is easily substituted onto the triazine ring under weakly basic conditions.

In this work, we developed another application for polymer-type triazine condensing reagents: immobilization by well-established ROMP (ring opening metathesis polymerization) method, in which the reaction proceeds rapidly and with high yield under mild neutral conditions. The dramatically expanded ROMP methodology, based on the work of Grubbs et al. in the 1990s, has been developed as an effective method for acquiring high-loading polymer reagents by polymerizing the reagent unit as a monomer. ${ }^{27-31)}$ Barrett et al. actively developed ROMP-gel supported reagents using this methodology, and reported many excellent immobilized reagents. ${ }^{4,9,32-34)}$ These reagents have several advantages in addition to high-loading, e.g., high tolerance of the methathesis catalysts for diverse functionalities, and readily available monomers from inexpensive precursors. Recently, ROMP supported coupling reagents carrying fluoroformamidinium or 2-bromopyridinium were also reported. ${ }^{11)}$ In this case, however, preparation of the monomers, which requires opera- tion of $3-4$ steps, seems not to be very easy.

Our monomer 1a was readily prepared by reacting cyanuric chloride consecutively with 5-norbornene-2-methanol and $\mathrm{MeOH}$ (Chart 1). A $\mathrm{CH}_{2} \mathrm{Cl}_{2}$ solution of the resulting monomer and cross-linker $2^{35)}$ in a mixing ratio of $p: q$, as shown in Table 1, was allowed to react in the presence of $0.1 \mathrm{~mol} \%$ Grubbs' catalyst 3 to produce four kinds of polymer with cross-linking percentages of $10,30,50$ and $100 \%$. The polymer reagents exhibited condensation activity when treated with $N$-methylmorpholine (NMM). The activated structure can be thought of that as shown in Fig. 1. Free chloride ion derived from chlorotriazine was titrated to allow determination of the average molecular weight per active unit (Table 1). ${ }^{19)}$ Polymers with cross-linking at $50 \%$ or less were found to show higher loading than that with $100 \%$ cross-linking.
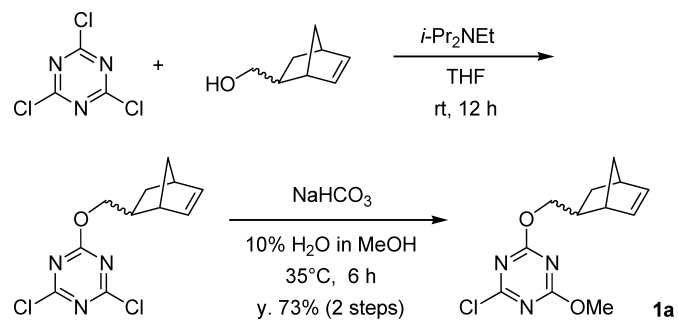

Chart 1. Preparation of Monomer 1a

Table 1. Synthesis of ROMP-Trz $-\mathrm{Cl}$
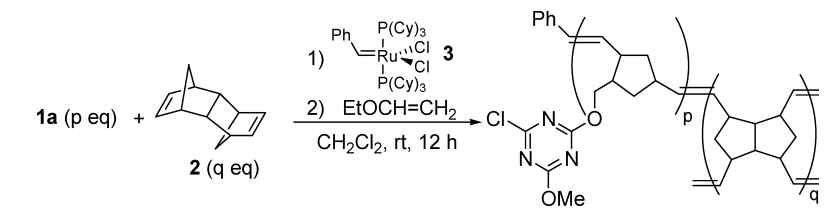

\begin{tabular}{lcrcc}
\hline \hline $\begin{array}{c}\mathrm{ROMP}- \\
\mathrm{Trz}\end{array} \mathrm{Cl}^{-\mathrm{Cl}}$ & $\begin{array}{c}\text { Degree of } \\
\text { cross-linking }^{a)}\end{array}$ & $\mathrm{p}: \mathrm{q}$ & $\mathrm{meq} / \mathrm{g}$ & $\mathrm{MW}_{\text {aver }}{ }^{b)}$ \\
\hline $\mathrm{Trz}_{10}$ & $10 \%$ & $10: 1$ & 2.43 & 412 \\
$\mathrm{Trz}_{30}$ & $30 \%$ & $10: 3$ & 2.55 & 392 \\
$\mathrm{Trz}_{50}$ & $50 \%$ & $2: 1$ & 2.30 & 436 \\
$\mathrm{Trz}_{100}$ & $100 \%$ & $1: 1$ & 1.94 & 515 \\
\hline
\end{tabular}

a) The degree of cross-linking was represented by the mole ratio of cross-linker 2 to the monomer used in the reaction. b) Average molecular weight per active unit; $\mathrm{MW}_{\text {aver }}=1000 /(\mathrm{meq} / \mathrm{g})$. 
A coupling reaction between phenylpropionic acid $\mathbf{5}$ and phenethylamine 6 was conducted using each polymer ( 2 eq) in various solvents (Table 2). ${ }^{36)}$ The use of $\mathrm{CH}_{2} \mathrm{Cl}_{2}$ and THF resulted in production of the amide in high yield, while the use of $\mathrm{MeOH}$ resulted in a slightly lower yield. Disappointingly, only small amounts of amide were obtained in water. The observed solvent effect may be correlated to the extent

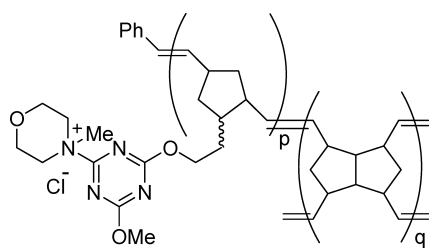

Fig. 1. Activated Structure of the Polymer Reagent (ROMP-Trz-MM)

Table 2. Amidation Activity of ROMP-Trz $(x=10-100)$ in Several Solvents

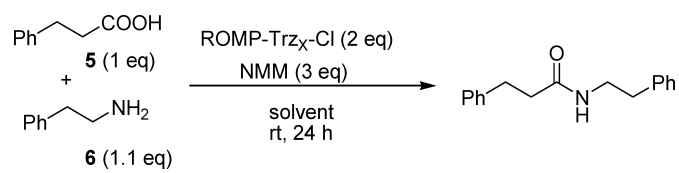

\begin{tabular}{|c|c|c|c|c|}
\hline \multirow{2}{*}{ ROMP-Trz $x-\mathrm{Cl}$} & \multicolumn{4}{|c|}{ Yield $(\%)^{a)}$} \\
\hline & $\mathrm{CH}_{2} \mathrm{Cl}_{2}$ & THF & $\mathrm{MeOH}$ & $\mathrm{H}_{2} \mathrm{O}$ \\
\hline$x=10$ & 92 & 93 & 71 & 2 \\
\hline 30 & 96 & 96 & 73 & 7 \\
\hline 50 & 99 & 97 & 82 & 15 \\
\hline 100 & 97 & 90 & 90 & 21 \\
\hline $\mathrm{ROMP}(\mathrm{OH})-\mathrm{Trz}_{50}-\mathrm{Cl}$ & 98 & 84 & 90 & 2 \\
\hline
\end{tabular}

a) The yield was determined by NMR. of polymer swelling; no swelling occurs in water (Table 3 ). ROMP-Trz $10^{-} \mathrm{Cl}$ and $\mathrm{Trz}_{30}-\mathrm{Cl}$, which are cross-linked to a lesser extent than ROMP-Trz ${ }_{50}-\mathrm{Cl}$, became sticky when swollen in $\mathrm{CH}_{2} \mathrm{Cl}_{2}$, and the gel particles tended to aggregate during shaking and thus clogged the filter, so general filtering could not be used. We employed ROMP-Trz ${ }_{50}-\mathrm{Cl}$, which has a lower average molecular weight than $\mathrm{Trz}_{100}-\mathrm{Cl}$ (Table 1), in this study.

Coupling reactions between several kinds of carboxylic acids and amines were conducted using ROMP-Trz ${ }_{50}-\mathrm{Cl}$ in $\mathrm{CH}_{2} \mathrm{Cl}_{2}$ or $\mathrm{MeOH}$ (Table 4). The reaction can be performed by a very simple procedure, mixing a carboxylic acid, an amine, and NMM together with the polymer. After completion of the reaction, NMM and amine remaining in the filtrate were easily removed by extraction using Merck Extrelut $^{\mathbb{R}}$. Amides were generally obtained in good yield in $\mathrm{CH}_{2} \mathrm{Cl}_{2}$. A lower yield was obtained for 3,5-di- $t$-butylbenzoic acid (run 7), probably because diffusion of the bulky carboxylic acid inside the polymer was hindered, and thus decomposition of the reagent by elimination of $\mathrm{CH}_{3} \mathrm{Cl}$ from the activated triazino moiety (ROMP-Trz-MM) might compete. ${ }^{22)}$

An important characteristic of the condensing reagent DMT-MM, which is the basis of this polymer reagent, is its

Table 3. Swelling Ratio ${ }^{a)}$ of ROMP-Trz ${ }_{50}-\mathrm{Cl}$ and $\mathrm{ROMP}(\mathrm{OH})-\mathrm{Trz}_{50}-\mathrm{Cl}$

\begin{tabular}{|c|c|c|c|c|}
\hline & $\mathrm{CH}_{2} \mathrm{Cl}_{2}$ & THF & $\mathrm{MeOH}$ & $\mathrm{H}_{2} \mathrm{O}$ \\
\hline ROMP-Trz $_{50}-\mathrm{Cl}$ & $230 \%$ & $180 \%$ & $20 \%$ & $0 \%$ \\
\hline $\operatorname{ROMP}(\mathrm{OH})-\mathrm{Trz}_{50}-\mathrm{Cl}$ & $150 \%$ & $150 \%$ & $60 \%$ & $0 \%$ \\
\hline
\end{tabular}

a) The swelling ratios were represented by the ratio of increased volume of the polymer by swelling to the initial volume of dried polymer.

Table 4. Dehydrocondensation Using ROMP-Trz $50-\mathrm{Cl}$ or $\mathrm{ROMP}(\mathrm{OH})-\mathrm{Trz}_{50}-\mathrm{Cl}$

$$
\begin{aligned}
& \text { ROMP-Trz } 50-\mathrm{Cl} \text { (2 eq) } \\
& \text { or ROMP(OH)-Trz }{ }_{50}-\mathrm{Cl}(2 \mathrm{eq})
\end{aligned}
$$

\begin{tabular}{|c|c|c|c|c|c|}
\hline \multirow{2}{*}{ Run } & \multirow{2}{*}{ Acid } & \multirow{2}{*}{ Amine } & \multicolumn{2}{|c|}{ Yield $(\%)^{a)}$ ROMP-Trz ${ }_{50}-\mathrm{Cl}$} & \multirow{2}{*}{$\frac{\text { Yield }(\%)^{a)} \mathrm{ROMP}(\mathrm{OH})-\mathrm{Trz}_{50}-\mathrm{Cl}}{\mathrm{MeOH}}$} \\
\hline & & & $\mathrm{CH}_{2} \mathrm{Cl}_{2}$ & $\mathrm{MeOH}$ & \\
\hline 1 & 5 & & 80 & 84 & 98 \\
\hline 2 & 5 & & 95 & 90 & 96 \\
\hline 3 & 5 & & 84 & 79 & 92 \\
\hline 4 & & & 91 & 71 & 87 \\
\hline 5 & $-\mathrm{COOH}$ & 6 & 95 & 74 & 80 \\
\hline 6 & $\mathrm{CH}_{3}\left(\mathrm{CH}_{2}\right)_{10} \mathrm{COOH}$ & 6 & 85 & 86 & 93 \\
\hline 7 & $t$-Bu & 6 & 67 & 53 & 87 \\
\hline 8 & $\mathrm{CH}_{3} \mathrm{COONa}$ & & $-^{b)}$ & 83 & 90 \\
\hline 9 & & 7 & -b) $^{b}$ & 86 & $98^{c)}$ \\
\hline
\end{tabular}

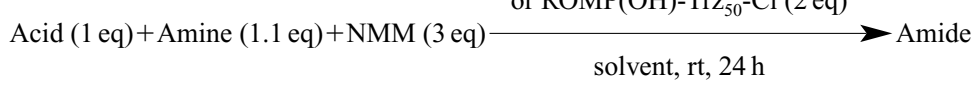

a) Isolated yield. b) Not performed. c) A slight epimerization (1.3\%) was observed by HPLC. 

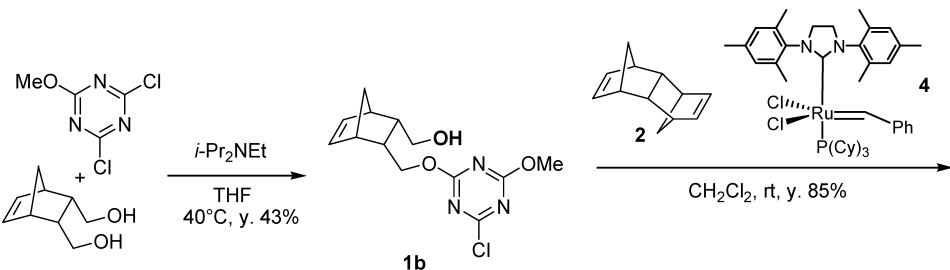

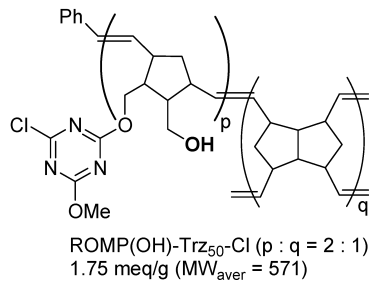

Chart 2. Synthesis of ROMP(OH)-Trz ${ }_{50}-\mathrm{Cl}$

high dehydrocondensing ability in water or $\mathrm{MeOH} .^{23)}$ These solvents are not only inexpensive and eco-friendly, but can also suppress the aforementioned decomposition of the reagent by solvation; thus, these solvents are the preferred media in which to conduct the reaction. As mentioned above, the observed yields for amide-formation using ROMP-Trz ${ }_{50}$ $\mathrm{Cl}$ in $\mathrm{MeOH}$ and water were moderate and poor, respectively. This was probably due to the lower hydrophilicity of the polymer, which resulted in its low swelling ratio.

In order to enhance the affinity of the polymer for protic solvents, we attempted to introduce hydroxyl groups to the polymer chain by using monomer $\mathbf{1 b}$ instead of $\mathbf{1 a}$ (Chart 2). The swelling ratio of the resulting polymer $\mathrm{ROMP}(\mathrm{OH})$ $\mathrm{TrZ}_{50}-\mathrm{Cl}$, in $\mathrm{CH}_{2} \mathrm{Cl}_{2}$ and THF decreased compared to that of ROMP-Trz ${ }_{50}-\mathrm{Cl}$, but tripled in $\mathrm{MeOH}$ (Table 3), and the yield of the dehydrocondensation between phenylpropionic acid and phenethylamine in $\mathrm{MeOH}$ was improved. As shown in Table 4, the yield of amides in $\mathrm{MeOH}$ increased for all substrates, including 3,5-di-t-butylbenzoic acid, which had a low yield with ROMP-Trz ${ }_{50}-\mathrm{Cl}$ (run 7). $\mathrm{N}$-Acetylation of phenylalanine methyl ester hydrochloride proceeded effectively using sodium acetate, which is more practical than acetyl chloride or acetic anhydride (run 8). Reaction of BocLeu-OH and H-Phe-OMe gave the corresponding dipeptide in $98 \%$ yield with a slight epimerization $\left(1.3 \%{ }^{37)}\right.$; run 9 ). Unfortunately, $\mathrm{ROMP}(\mathrm{OH})-\mathrm{Trz}_{50}-\mathrm{Cl}$ did not show swelling in water, either, so the yield of amide in this solvent was not improved.

In conclusion, we have succeeded in developing new triazine-type polymers ROMP-Trz ${ }_{50}-\mathrm{Cl}$ and $\mathrm{ROMP}(\mathrm{OH})-\mathrm{Trz}_{50^{-}}$ $\mathrm{Cl}$, synthesized by the ROMP methodology, as immobilized dehydrocondensing reagents. These reagents work efficiently and can be prepared relatively at low cost. High-loading immobilization by ROMP results in the development of polymers with lower average molecular weights in comparison with conventional solid-supported condensing reagents, therefore, the waste arising from the immobilized reagent can be reduced. Since these ROMP-Trz-Cl reagents, especially $\mathrm{ROMP}(\mathrm{OH})-\mathrm{Trz}_{50}-\mathrm{Cl}$, can be utilized in $\mathrm{MeOH}$, they can also be applied to the substrates which are difficult to dissolve in the less polar solvents. Several types of norbornene derivatives, which contain alcohol, aldehyde, and amine functional groups, are available, so additional structural modification should be relatively easy to achieve. Further studies with the aim of improving the hydrophilicity of the polymers as well as recycling the reagents according to our method for regeneration of 4-chloro-2,6-dimethoxy1,3,5-triazine $(\mathrm{CDMT})^{38)}$ are currently underway.

\section{Experimental}

Dry THF and $\mathrm{CH}_{2} \mathrm{Cl}_{2}$ were distilled in the usual manner. 2,4-Dichloro-6- methoxy-1,3,5-triazine was prepared by modification of reported procedure. ${ }^{39)}$ Other chemicals and solvents were obtained from commercial sources and used without further purification. IR spectra were measured on a Nicolet FT-IR AVATAR 360 spectrometer. ${ }^{1} \mathrm{H}$-NMR spectra were taken on a Bruker DPX-400 spectrometer. ESI-MS and EI-MS spectra were recorded on a Waters Micromass ZQ 2000 spectrometer and JEOL JMS-700 spectrometer, respectively.

Preparation of 5-(4-Chloro-6-methoxy-1,3,5-triazin-2-yloxymethyl)norbornene (1a) Cyanuric chloride $(21.57 \mathrm{~g}, 117.0 \mathrm{mmol})$ was added to a mixture of 5-norbornene-2-methanol $(7.26 \mathrm{~g}, 58.5 \mathrm{mmol})$ and diisopropylethylamine $(9.07 \mathrm{~g}, 70.2 \mathrm{mmol})$ in dry THF $(64.5 \mathrm{ml})$ at $0{ }^{\circ} \mathrm{C}$ under $\mathrm{N}_{2}$ atmosphere. After stirring for $12 \mathrm{~h}$ at $\mathrm{rt}, \mathrm{Et}_{2} \mathrm{O}(150 \mathrm{ml})$ was added, and the mixture was filtered and evaporated. The residue was subjected to chromatography (hexane : $\mathrm{AcOEt}=93: 7$ ) to give a mixture of 5-(4,6-dichloro-1,3,5-triazin-2yloxymethyl)norbornene and by-products derived from cyanuric chloride. The product mixture was dissolved in $\mathrm{MeOH}(100 \mathrm{ml})$ containing $10 \%$ water, and $\mathrm{NaHCO}_{3}(9.83 \mathrm{~g}, 117.0 \mathrm{mmol})$ was added. After stirring for $6 \mathrm{~h}$ at $35^{\circ} \mathrm{C}$, almost all of the $\mathrm{MeOH}$ was removed by evaporation. Celite ${ }^{\circledR}, \mathrm{MgSO}_{4}$ and $\mathrm{CH}_{2} \mathrm{Cl}_{2}(100 \mathrm{ml})$ were added to the residue, and the mixture was filtered through Celite ${ }^{\circledR}$ and evaporated. The residue was purified by column chromatography (hexane: $\mathrm{AcOEt}=9: 1)$ to give the title compound $(11.45 \mathrm{~g}$, $73 \%$, endo and exo $(1.8: 1)$ mixture) as a colorless oil. ${ }^{1} \mathrm{H}-\mathrm{NMR}\left(\mathrm{CDCl}_{3}\right) \delta$ : 0.64 (endo $1 \mathrm{H}$, ddd, $J=11.8,4.3,2.7 \mathrm{~Hz}$ ), 1.24 (exo $1 \mathrm{H}$, ddd, $J=11.8,4.1$, $3.8 \mathrm{~Hz}$ ), 1.30 (endo $1 \mathrm{H}$, br d, $J=8.3 \mathrm{~Hz}$ ), $1.42-1.32$ (exo $3 \mathrm{H}, \mathrm{m}), 1.49$ (endo $1 \mathrm{H}$, br d, $J=8.3 \mathrm{~Hz}$ ), 1.96-1.87 (endo $1 \mathrm{H}$, exo $1 \mathrm{H}, \mathrm{m}$ ), 2.62-2.52 (endo $1 \mathrm{H}, \mathrm{m}$ ), $2.90-2.82$ (endo $1 \mathrm{H}$, exo $2 \mathrm{H}, \mathrm{m}$ ), 3.01 (endo $1 \mathrm{H}, \mathrm{br}$ ), 4.01 (endo $1 \mathrm{H}, \mathrm{dd}, J=10.5,9.5 \mathrm{~Hz}$ ), 4.07 (exo $3 \mathrm{H}, \mathrm{s}$ ), 4.06 (endo $3 \mathrm{H}, \mathrm{s}$ ), 4.21 (endo $1 \mathrm{H}$, dd, $J=10.5,6.6 \mathrm{~Hz}$ ), 4.32 (exo $1 \mathrm{H}, \mathrm{dd}, J=10.6,9.5 \mathrm{~Hz}$ ), 4.51 (exo $1 \mathrm{H}, \mathrm{dd}$, $J=10.6,6.3 \mathrm{~Hz}$ ), 5.98 (endo $1 \mathrm{H}, \mathrm{dd}, J=5.7,2.9 \mathrm{~Hz}$ ), 6.13-6.08 (exo $2 \mathrm{H}$, m), 6.19 (endo $1 \mathrm{H}, \mathrm{dd}, J=5.7,3.0 \mathrm{~Hz}$ ). Anal. Calcd for $\mathrm{C}_{12} \mathrm{H}_{14} \mathrm{~N}_{3} \mathrm{ClO}_{2}$ : C, 53.84; H, 5.27; N, 15.70. Found: C, 53.58; H, 5.19; N, 15.78. MS (ESI) $m / z$ : $268\left(\mathrm{MH}^{+}\right), 270\left(\mathrm{MH}^{+}\right)$. HR-MS (EI) $m / z$ Calcd for $\mathrm{C}_{12} \mathrm{H}_{14} \mathrm{~N}_{3} \mathrm{ClO}_{2}\left(\mathrm{M}^{+}\right)$: 267.0775; Found: 267.0777.

Preparation of 5-(4-Chloro-6-methoxy-1,3,5-triazin-2-yloxymethyl)-6hydroxymethylnorbornene (1b) This compound would be undergoing self-polymerization in a concentrated solution. It should be used immediately after concentration. To a dry THF solution $(32.4 \mathrm{ml})$ of 5 -norbornene2,3-endo-dimethanol ( $5.0 \mathrm{~g}, 32.4 \mathrm{mmol})$ was added 2,4-dichloro-6-methoxy1,3,5-triazine $(7.0 \mathrm{~g}, 38.9 \mathrm{mmol})$ and diisopropylethylamine $(4.19 \mathrm{~g}$, $32.4 \mathrm{mmol}$ ) at $0{ }^{\circ} \mathrm{C}$. After stirring for $30 \mathrm{~min}$ at $\mathrm{rt}$, the mixture was heated at $40^{\circ} \mathrm{C}$ for $16 \mathrm{~h}$. The resulting solution was poured into water $(100 \mathrm{ml})$ and extracted with AcOEt $(100 \mathrm{ml})$. The organic layer was evaporated, and the residual oil was immediately subjected to column chromatography to give the title compound $(4.1 \mathrm{~g}, 43 \%)$ as a colorless solid. mp: $109-110^{\circ} \mathrm{C}$ (dec.). ${ }^{1} \mathrm{H}-\mathrm{NMR}\left(\mathrm{CDCl}_{3}\right) \delta: 1.39(1 \mathrm{H}, \mathrm{br} \mathrm{d}, J=8.4 \mathrm{~Hz}), 1.55(1 \mathrm{H}, \mathrm{dt}, J=8.4$, $1.8 \mathrm{~Hz}), 2.56-2.47(1 \mathrm{H}, \mathrm{m}), 2.76-2.67(1 \mathrm{H}, \mathrm{m}), 2.99(1 \mathrm{H}, \mathrm{br} \mathrm{s}), 3.03(1 \mathrm{H}$, br s), $3.39(1 \mathrm{H}, \mathrm{dd}, J=10.6,7.9 \mathrm{~Hz}), 3.51(1 \mathrm{H}, \mathrm{dd}, J=10.6,7.4 \mathrm{~Hz}), 4.06$ $(3 \mathrm{H}, \mathrm{s}), 4.14(1 \mathrm{H}, \mathrm{dd}, J=10.7,8.9 \mathrm{~Hz}), 4.33(1 \mathrm{H}, \mathrm{dd}, J=10.7,7.1 \mathrm{~Hz})$, $6.23-6.16(2 \mathrm{H}, \mathrm{m}) .{ }^{13} \mathrm{C}-\mathrm{NMR}\left(\mathrm{CDCl}_{3}, 100 \mathrm{MHz}\right) \delta: 40.9,45.1,45.9,46.0$, 49.7, 56.5, 63.2, 70.4, 135.4, 136.2, 172.3, 172.9, 173.1. Anal. Calcd for $\mathrm{C}_{13} \mathrm{H}_{16} \mathrm{~N}_{3} \mathrm{ClO}_{3}$ : C, 52.44; H, 5.42; N, 14.11. Found: C, 52.27; H, 5.41; N, 14.11. MS (ESI): $m / z=298\left(\mathrm{MH}^{+}\right), 300\left(\mathrm{MH}^{+}\right)$. HR-MS (EI) $\mathrm{m} / z$ Calcd for $\mathrm{C}_{13} \mathrm{H}_{16} \mathrm{~N}_{3} \mathrm{ClO}_{3}\left(\mathrm{M}^{+}\right)$: 297.0880; Found: 297.0895 .

General Procedure for Synthesis of ROMP-Trz - -Cl. ROMP-Trz ${ }_{50}-\mathrm{Cl}$ To a solution of monomer 1a $(5.16 \mathrm{~g}, 19.28 \mathrm{mmol})$ and cross-linker $\left.\mathbf{2}^{35}\right)$ $(1.53 \mathrm{~g}, 9.64 \mathrm{mmol})$ in dry $\mathrm{CH}_{2} \mathrm{Cl}_{2}(96 \mathrm{ml})$ was added a solution of Grubbs' catalyst $3(15.9 \mathrm{mg}, 0.019 \mathrm{mmol})$ in $\mathrm{CH}_{2} \mathrm{Cl}_{2}(1 \mathrm{ml})$ at rt. Gelation occurred within a few minutes. The gel was allowed to stand for $12 \mathrm{~h}$ to complete the reaction. Ethyl vinyl ether $(1 \mathrm{ml})$ and $\mathrm{CH}_{2} \mathrm{Cl}_{2}(100 \mathrm{ml})$ were added, and the gel was crushed to small pieces $(c a .2-3 \mathrm{~mm})$. After stirring for $12 \mathrm{~h}$, the polymer was passed through a sieve $(250 \mu \mathrm{m})$ and washed repeatedly with 
$\mathrm{CH}_{2} \mathrm{Cl}_{2}$ and $\mathrm{Et}_{2} \mathrm{O}$, and dried under reduced pressure to give ROMP-Trz ${ }_{50}-\mathrm{C}$ $(5.69 \mathrm{~g}, 85 \%, 2.30 \mathrm{meq} / \mathrm{g})$ as colorless powder. Amount of chloride loaded on the polymer was determined according to our procedure previously described. ${ }^{19)}$ IR (ATR) $\mathrm{cm}^{-1}: 1557,1533,1437,1294,1034,814$

ROMP-Trz $(\mathrm{OH})_{50}-\mathrm{Cl}$ : Colorless powder. IR (ATR) $\mathrm{cm}^{-1}: 1558,1534$ 1438, 1296, 1035, 814 .

General Procedure for Amide Formation. $N$-Phenethyl-3-phenylpropanamide A solution of phenylpropionic acid $(15.0 \mathrm{mg}, 0.10 \mathrm{mmol})$, phenethylamine $(13.3 \mathrm{mg}, 0.11 \mathrm{mmol})$, and $N$-methylmorpholine $(30.3 \mathrm{mg}$, $0.30 \mathrm{mmol})$ in $\mathrm{CH}_{2} \mathrm{Cl}_{2}(2.0 \mathrm{ml})$ was added to $\mathrm{ROMP}-\mathrm{TrZ}_{50}-\mathrm{Cl}(87.2 \mathrm{mg}$, $0.20 \mathrm{mmol})$. After shaken for $24 \mathrm{~h}$ at $\mathrm{rt}, \mathrm{Et}_{2} \mathrm{O}(\mathrm{ca} .10 \mathrm{ml})$ was added in order to shrink the polymer, and then, the reaction mixture was filtered. The polymer was rinsed twice with $\mathrm{AcOEt}(5 \mathrm{ml})$, and the washings and filtrates were combined. The resulting solution was poured into the Merk Extrelut ${ }^{\mathbb{R}}$ NT20 column containing $0.01 \mathrm{M} \mathrm{HCl}(10 \mathrm{ml})$. The column was eluted with AcOEt $(100 \mathrm{ml})$, and the filtrate was evaporated to give $\mathrm{N}$-phenethyl-3-phenylpropanamide $(25.0 \mathrm{mg}, 99 \%)$. Colorless crystals. mp $94.5-95.5^{\circ} \mathrm{C} .{ }^{1} \mathrm{H}-$ $\operatorname{NMR}\left(\mathrm{CDCl}_{3}\right) \delta: 2.41(3 \mathrm{H}, \mathrm{t}, J=7.7 \mathrm{~Hz}), 2.73(2 \mathrm{H}, \mathrm{t}, J=6.9 \mathrm{~Hz}), 2.94(2 \mathrm{H}$, $\mathrm{t}, J=7.7 \mathrm{~Hz}), 3.47(2 \mathrm{H}, \mathrm{td}, J=6.9,6.0 \mathrm{~Hz}), 5.37(1 \mathrm{H}, \mathrm{br} \mathrm{s}), 7.16-7.30(5 \mathrm{H}$ m). IR (KBr) cm ${ }^{-1}: 3299,1635,1544$. MS (ESI) $m / z: 254\left(\mathrm{MH}^{+}\right)$.

$N, 3$-Diphenylpropanamide: Colorless crystals. mp: $98-99^{\circ} \mathrm{C}$. IR $(\mathrm{KBr})$ $\mathrm{cm}^{-1}: 3311,1652,1601,1534,1497,1443,1316,1076,756,697 .{ }^{1} \mathrm{H}-\mathrm{NMR}$ $\left(\mathrm{CDCl}_{3}\right) \delta: 2.65(2 \mathrm{H}, \mathrm{t}, J=7.6 \mathrm{~Hz}), 3.05(2 \mathrm{H}, \mathrm{t}, J=7.6 \mathrm{~Hz}), 7.09(2 \mathrm{H}, \mathrm{t}$, $J=7.4 \mathrm{~Hz}), 7.19-7.33(6 \mathrm{H}, \mathrm{m}), 7.42(2 \mathrm{H}, \mathrm{d}, J=7.9 \mathrm{~Hz})$. MS (ESI) $\mathrm{m} / \mathrm{z}: 226$ $\left(\mathrm{MH}^{+}\right)$.

$\mathrm{N}$-(4-Chlorophenyl)-3-phenylpropanamide: Colorless crystals. $\mathrm{mp}$ $141.5-143^{\circ} \mathrm{C}$. IR (KBr) cm ${ }^{-1}$ : $3294,1658,1590,1519,1488,1310,1093$, 821, 694. ${ }^{1} \mathrm{H}-\mathrm{NMR}\left(\mathrm{CDCl}_{3}\right) \delta: 2.65(2 \mathrm{H}, \mathrm{t}, J=7.5 \mathrm{~Hz}), 3.05(2 \mathrm{H}, \mathrm{t}$, $J=7.5 \mathrm{~Hz}), 6.98(1 \mathrm{H}, \mathrm{br} \mathrm{s}), 7.19-7.33(7 \mathrm{H}, \mathrm{m}), 7.37(2 \mathrm{H}, \mathrm{d}, J=8.7 \mathrm{~Hz}) . \mathrm{MS}$ (ESI) $m / z: 260\left(\mathrm{MH}^{+}\right)$.

$N$-(1-Phenylethyl)-3-phenylpropanamide: Colorless crystals. mp 50 $51^{\circ} \mathrm{C}$. IR $(\mathrm{KBr}) \mathrm{cm}^{-1}: 3260,1646,1557 .{ }^{1} \mathrm{H}-\mathrm{NMR}\left(\mathrm{CDCl}_{3}\right) \delta: 1.40(3 \mathrm{H}, \mathrm{d}$, $J=6.9 \mathrm{~Hz}), 2.46-2.50(2 \mathrm{H}, \mathrm{m}), 2.97(2 \mathrm{H}, \mathrm{t}, J=7.5 \mathrm{~Hz}), 5.10(1 \mathrm{H}, \mathrm{qd}$, $J=6.9,7.2 \mathrm{~Hz}), 5.51(1 \mathrm{H}, \mathrm{br} \mathrm{s}), 7.16-7.32(10 \mathrm{H}, \mathrm{m})$. MS (ESI) $m / z: 254$ $\left(\mathrm{MH}^{+}\right)$.

$N$-Phenethylcinnamamide: Colorless needles. mp $126-127^{\circ} \mathrm{C}$. IR (KBr) $\mathrm{cm}^{-1}: 3299,1650,1614,1544 .{ }^{1} \mathrm{H}-\mathrm{NMR}\left(\mathrm{CDCl}_{3}\right) \delta: 2.89(2 \mathrm{H}, \mathrm{t}, J=6.9 \mathrm{~Hz})$, $3.66(2 \mathrm{H}, \mathrm{td}, J=6.9,6.0 \mathrm{~Hz}), 5.73(1 \mathrm{H}, \mathrm{brs}), 6.33(1 \mathrm{H}, \mathrm{d}, J=15.6 \mathrm{~Hz})$, $7.21-7.37(8 \mathrm{H}, \mathrm{m}), 7.45-7.50(2 \mathrm{H}, \mathrm{m}), 7.62(1 \mathrm{H}, \mathrm{d}, J=15.6 \mathrm{~Hz}) . \mathrm{MS}(\mathrm{EI})$ $m / z: 251\left(\mathrm{M}^{+}\right)$.

4-Chloro- $N$-phenethylbenzamide: Colorless crystals. mp $137-138^{\circ} \mathrm{C}$. IR $(\mathrm{KBr}) \mathrm{cm}^{-1}: 3346,1638,1596,1542,1488,1316,1094,844,752,699 .{ }^{1} \mathrm{H}-$ NMR $\left(\mathrm{CDCl}_{3}\right) \delta: 2.93(2 \mathrm{H}, \mathrm{t}, J=6.8 \mathrm{~Hz}), 3.72(2 \mathrm{H}, \mathrm{td}, J=6.8,6.0 \mathrm{~Hz}), 6.07$ $(1 \mathrm{H}, \mathrm{brs}), 7.20-7.28(3 \mathrm{H}, \mathrm{m}), 7.30-7.40(4 \mathrm{H}, \mathrm{m}), 7.59-7.64(2 \mathrm{H}, \mathrm{m})$ MS (ESI) $m / z: 260\left(\mathrm{MH}^{+}\right)$.

$\mathrm{N}$-Phenethyldodecanamide: Colorless crystals. mp $72-73^{\circ} \mathrm{C}$. IR $(\mathrm{KBr})$ $\mathrm{cm}^{-1}: 3311,2921,2859,1641,1551,1463,1192,745,697 .{ }^{1} \mathrm{H}-\mathrm{NMR}$ $\left(\mathrm{CDCl}_{3}\right) \delta: 0.88(3 \mathrm{H}, \mathrm{t}, J=7.0 \mathrm{~Hz}), 1.21-1.34(16 \mathrm{H}, \mathrm{m}), 1.53-1.62(2 \mathrm{H}$, m), $2.11(2 \mathrm{H}, \mathrm{t}, J=7.6 \mathrm{~Hz}), 2.82(2 \mathrm{H}, \mathrm{t}, J=6.9 \mathrm{~Hz}), 3.52(2 \mathrm{H}, \mathrm{td}, J=6.9$, $6.0 \mathrm{~Hz}), 5.39(1 \mathrm{H}, \mathrm{brs}), 7.16-7.35(5 \mathrm{H}, \mathrm{m})$. MS (ESI) $m / z: 304\left(\mathrm{MH}^{+}\right)$.

3,5-Di-tert-butyl- $N$-phenethylbenzamide: Colorless crystals. mp 202$203^{\circ} \mathrm{C}$. IR $(\mathrm{KBr}) \mathrm{cm}^{-1}: 3282,2960,1635,1598,1539,1332,1276,1194$, 742, 694. ${ }^{1} \mathrm{H}-\mathrm{NMR}\left(\mathrm{CDCl}_{3}\right) \delta: 1.32(18 \mathrm{H}, \mathrm{s}), 2.95(2 \mathrm{H}, \mathrm{t}, J=6.8 \mathrm{~Hz}), 3.72$ $(2 \mathrm{H}, \mathrm{td}, J=6.8,6.0 \mathrm{~Hz}), 6.07(1 \mathrm{H}, \mathrm{brs}), 7.22-7.29(3 \mathrm{H}, \mathrm{m}), 7.30-7.37$ $(2 \mathrm{H}, \mathrm{m}), 7.49(2 \mathrm{H}, \mathrm{d}, J=1.8 \mathrm{~Hz}), 7.54(1 \mathrm{H}, \mathrm{t}, J=1.8 \mathrm{~Hz})$ MS (ESI) $m / z: 338$ $\left(\mathrm{MH}^{+}\right)$.

Boc-Leu-Phe-OMe: Colorless crystals. mp $83.5-84^{\circ} \mathrm{C}$. IR $(\mathrm{KBr}) \mathrm{cm}^{-1}$ : $3342,3307,1743,1666,1523 .{ }^{1} \mathrm{H}-\mathrm{NMR}\left(\mathrm{CDCl}_{3}\right) \delta: 0.91(3 \mathrm{H}, \mathrm{d}, J=6.2 \mathrm{~Hz})$, $0.92(3 \mathrm{H}, \mathrm{d}, J=6.4 \mathrm{~Hz}), 1.24-1.31(1 \mathrm{H}, \mathrm{m}), 1.44(9 \mathrm{H}, \mathrm{s}), 1.57-1.69(2 \mathrm{H}$ $\mathrm{m}), 3.09(1 \mathrm{H}, \mathrm{dd}, J=5.9,13.7 \mathrm{~Hz}), 3.14(1 \mathrm{H}, \mathrm{dd}, J=5.8,13.7 \mathrm{~Hz}), 3.71(3 \mathrm{H}$, s), $4.07(1 \mathrm{H}, \mathrm{brs}), 4.77(1 \mathrm{H}, \mathrm{brs}), 4.84(1 \mathrm{H}, \mathrm{td}, J=5.9,7.8 \mathrm{~Hz}), 6.44(1 \mathrm{H}$, brd, $J=7.5 \mathrm{~Hz}), 7.08-7.13(2 \mathrm{H}, \mathrm{m}), 7.21-7.31(3 \mathrm{H}, \mathrm{m})$. MS (EI) $m / z: 392$ $\left(\mathrm{M}^{+}\right)$.

$N$-Acetylphenylalanine Methyl Ester: Colorless crystals. mp $89.5-90{ }^{\circ} \mathrm{C}$. IR $(\mathrm{KBr}) \mathrm{cm}^{-1}: 1752,1648,1537 .{ }^{1} \mathrm{H}-\mathrm{NMR}\left(\mathrm{CDCl}_{3}\right) \delta: 1.97(3 \mathrm{H}, \mathrm{s}), 3.09$ $(1 \mathrm{H}, \mathrm{dd}, J=5.8,13.9 \mathrm{~Hz}), 3.14(1 \mathrm{H}, \mathrm{dd}, J=5.9,13.9 \mathrm{~Hz}), 3.72(3 \mathrm{H}, \mathrm{s}), 4.88$ $(1 \mathrm{H}, \mathrm{td}, J=5.8,7.9 \mathrm{~Hz}), 6.00(1 \mathrm{H}, \mathrm{brs}), 7.07-7.12(2 \mathrm{H}, \mathrm{m}), 7.22-7.32$ $(3 \mathrm{H}, \mathrm{m})$. MS (ESI) $m / z: 222\left(\mathrm{MH}^{+}\right)$.

\section{References and Notes}

1) Uozumi Y., Yamada Y., Kagaku Furontia, 16, 155-163 (2006).
2) Parlow J. J., Curr. Opin. Drug Discovery Dev., 8, 757-775 (2005).

3) Gonthier E., Breinbauer R., Molecular Diversity, 9, 51—62 (2005).

4) Harned A. M., Zhang M., Vedantham P., Mukherjee S., Herpel R. H., Flynn D. L., Hanson P. R., Aldrichimica Acta, 38, 3-16 (2005).

5) Katritzky A. R., Suzuki K., Singh S. K., ARKIVOC, i, 12-35 (2004).

6) Barrett A. G. M., Hopkins B. T., Köbberling J., Chem. Rev., 102, 3301-3324 (2002). See also references therein.

7) Kirschning A., Monenschein H., Wittenberg R., Angew. Chem. Int Ed., 40, 650-679 (2001).

8) Ley S. V., Baxendale I. R., Bream R. N., Jackson P. S., Leach A. G., Longbottom D. A., Nesi M., Scott J. S., Storer R. I., Taylor S. J., J. Chem. Soc., Perkin Trans. 1, 2000, 3815-4195 (2000).

9) Thompson L. A., Curr. Opin. Chem. Biol., 4, 324-337 (2000).

10) Valeur E., Bradley M., Chem. Commun., 2005, 1164-1166 (2005).

11) Barrett A. G. M., Bibal B., Hopkins B. T., Köbberling J., Love A. C., Tedeschi L., Tetrahedron, 61, 12033-12041 (2005).

12) Filip S. V., Lejeune V., Vors J.-P., Martinez J., Cavelier F., Eur. J. Org. Chem., 2004, 1936-1939 (2004).

13) Donati D., Morelli C., Porcheddu A., Taddei M., J. Org. Chem., 69, 9316-9318 (2004).

14) Crosignani S., Gonzalez J., Swinnen D., Org. Lett., 6, 4579-4582 (2004).

15) Chinchilla R., Dodsworth D. J., Nájera C., Soriano J. M., Yus M., ARKIVOC, $\mathbf{x}, 41-47$ (2003).

16) Disadee W., Watanabe T., Ishikawa T., Synlett, 2003, 115-117 (2003).

17) Desai M. C., Stramiello L. M. S., Tetrahedron Lett., 34, 7685-7688 (1993).

18) Kaminski Z. J., Biopolymers, 55, 140-164 (2000).

19) Kunishima M., Yamamoto K., Watanabe Y., Hioki K., Tani S., Chem. Commun., 2005, 2698-2700 (2005)

20) Hioki K., Yamamoto K., Tani S., Kunishima M., "Peptide Science 2005," ed by Wakamiya T., The Japanese Peptide Society, Osaka, 2006, pp. 485-486.

21) Kunishima M., Kawachi C., Iwasaki F., Terao K., Tani S., Tetrahedron Lett., 40, 5327-5330 (1999).

22) Kunishima M., Kawachi C., Morita J., Terao K., Iwasaki F., Tani S., Tetrahedron, 55, 13159-13170 (1999).

23) Kunishima M., Kawachi C., Hioki K., Terao K., Tani S., Tetrahedron, 57, 1551-1558 (2001).

24) Kunishima M., Kitao A., Kawachi C., Watanabe Y., Iguchi S., Hioki K., Tani S., Chem. Pharm. Bull., 50, 549-550 (2002).

25) Falchi A., Giacomelli G., Porcheddu A., Taddei M., Synlett, 2000, $275-277$ (2000).

26) Armitt D. J., Aust. J. Chem., 54, 469 (2001)

27) Fu G. C., Nguyen S. T., Grubbs R. H., J. Am. Chem. Soc., 115, 9856 9857 (1993).

28) Schwab P., France M. B., Ziller J. W., Grubbs R. H., Angew. Chem. Int. Ed., 34, 2039-2041 (1995).

29) Scholl M., Ding S., Lee C. W., Grubbs R. H., Org. Lett., 1, 953-956 (1999).

30) Trnka T. M., Grubbs R. H., Acc. Chem. Res., 34, 18-29 (2001), and references cited therein.

31) Grubbs R. H., Sanford M., Mathematics, Physics and Chemistry, 56, $17-21$ (2002).

32) Fuchter M. J., Hoffman B. M., Barrett A. G. M., J. Org. Chem., 71, 724-729 (2006).

33) Barrett A. G. M., Hopkins B. T., Love A. C., Tedeschi L., Org. Lett., 6 , $835-837$ (2004).

34) Årstad E., Barrett A. G. M., Tedeschi L., Tetrahedron Lett., 44, 2703 2707 (2003).

35) Stille J. K., Frey D. A., J. Am. Chem. Soc., 81, 4273-4275 (1959).

36) When the reaction was conducted with 1.4 eq of $\mathrm{ROMP}_{-} \mathrm{Trz}_{50}{ }^{-} \mathrm{Cl}$ in $\mathrm{MeOH}$, the yield of amide decreased to $67 \%$ presumably due to inefficient heterogeneous conditions.

37) The epimerizatoin test was performed by HPLC analysis according to ref. 23.

38) Kunishima M., Hioki K., Wada A., Kobayashi H., Tani S., Tetrahedron Lett., 43, 3323-3326 (2002).

39) Dudley J. R., Thurston J. T., Schaefer F. C., Holm-Hansen D., Hull C. J., Adams P., J. Am. Chem. Soc., 73, 2986-2990 (1951). 